\title{
Duramycin-porphyrin Conjugates for Targeting of Phosphatidylethanolamine Using Photodynamic Therapy
}

Laura J Broughton ${ }^{a}$, Francesca Giuntini ${ }^{b}$, Huguette Savoiec, Francesca Brydenc, Ross W Boylec, Anthony Maraveyas $^{\mathrm{a}}$, Leigh A Madden ${ }^{\mathrm{d}}$

aHull York Medical School, University of Hull, Hull, UK, HU6 7RX.

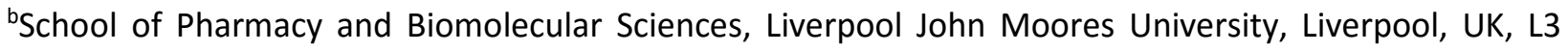
$2 \mathrm{AJ}$.

'Department of Chemistry, University of Hull, Hull, UK, HU6 7RX.

${ }^{\mathrm{d} S}$ Chool of Biological, Biomedical and Environmental Sciences, University of Hull, Hull, UK, HU6 7RX.

Address for correspondence:

Dr Leigh A Madden,

Allam Building,

University of Hull,

Cottingham Road,

Hull, UK,

HU6 7RX.

Email; L.A.Madden@hull.ac.uk. 


\begin{abstract}
Duramycin, through binding with phosphatidylethanolamine, has been shown to be a selective molecular probe for the targeting and imaging of cancer cells. Photodynamic therapy aims to bring about specific cytotoxic damage to tumours through delivery of a photosensitising agent and light irradiation. Conjugation to biological molecules that specifically target cancer has been shown to increase photosensitiser selectivity and decrease damage to surrounding normal tissue. Duramycin was conjugated to a porphyrin based photosensitiser via direct reaction to the $\varepsilon$-amino group on the lysine residue near duramycin's N-terminal and subsequently purified using RP-HPLC. Binding of the conjugate to ovarian and pancreatic cancer cell lines was assessed by flow cytometry. Light irradiation with a light fluence of $7.5 \mathrm{~J} / \mathrm{cm}^{2}$ was delivered to conjugate treated cancer cells and cell survival analysed by MTT assay. The conjugate detected phosphatidylethanolamine on all 4 cancer cell lines in a concentration dependent manner and conjugate plus irradiation effectively reduced cell survival at concentrations $>2.5 \mu \mathrm{M}$. Reduction in cell survival by conjugate plus irradiation was significantly enhanced, when compared to unconjugated duramycin in A2780, AsPC-1 and SK-OV-3 cancer cells. In this study we have shown that a duramycin-porphyrin conjugate retained good binding affinity for its target and, following irradiation, reduced cell survival of pancreatic and ovarian cancer cell lines.
\end{abstract}

\title{
Keywords
}

Porphyrin, Photodynamic therapy, Cancer, Duramycin, Phosphatidylethanolamine. 


\section{Introduction}

Duramycin is a small tetracyclic peptide produced by the bacterium Streptoverticillium cinnamoneus [1]. Only 19 amino acids in length duramycin is one of very few identified, relatively, short peptides to have a defined 3-dimensional structure [2]. This structure is stable due to the presence of 4 intramolecular covalent bridges formed via the amino acids lanthionine, methyllanthionine, lysinoalanine and betahydroxyaspartic acid [3]. This strength in structure may explain duramycin's resistance to thermal and proteolytic degradation [2]. Three internal covalent bridges stabilise duramycin's binding site which selectively recognises the ethanolamine head-group of the membrane phospholipid phosphatidylethanolamine (PE) [4]. Duramycin binds to PE with high specificity with a binding molar ratio of 1:1 [5]. PE is an abundant membrane phospholipid which is ubiquitous in eukaryotic cells. In quiescent cells PE is predominantly located on the inner cell membrane along with phosphatidylserine $[6,7]$. The asymmetrical distribution of PE and phosphatidylserine is enzymatically maintained by a group of ATP dependent aminophospholipid translocases [8,9]. On activation PE can become exposed on the outer cell membrane during a number of physiologically important processes such as apoptotic and necrotic cell death, reorganisation of the membrane during cytokinesis and initiation of the coagulation cascade [10-13]. Upregulation of cell surface PE expression has been observed in cancer cells, cancer derived microparticles and on the tumour endothelium of a variety of in vitro and in vivo tumours $[1,14-16]$.

Photodynamic therapy (PDT) is a minimally invasive treatment that can deliver selective cytotoxic activity towards cancer [17]. PDT requires three essential components; a photosensitising agent, light and oxygen. Accumulation of the photosensitiser (PS) at the site of cancer and activation with light at a specific wavelength causes the PS to transfer energy, via its excited triplet state, to molecular oxygen which is converted from its ground triplet state to an excited singlet state. This leads to the generation of cell damaging reactive oxygen species (ROS) which ultimately causes apoptotic or necrotic cell death $[17,18]$. As well as its direct cytotoxic effect on cancer, PDT can have anti-tumour effects via induction of the inflammatory response and damage to tumour vasculature $[19,20]$. PDT has been approved for treatment of a variety of cancer types including premalignant and malignant skin cancers [21, 22], early carcinomas of the oral cavity, pharynx, and larynx [23], cancers of the GI tract [24], prostate cancer, bladder cancer, non-small cell lung cancer and brain tumours [17]. A number of PS have been approved for use in clinical oncology including m-THCP (meta-tetrahydroxyphenylchlorin, Foscan ${ }^{\circ}$ ), ALA (5aminolevulinic acid, Levulan ${ }^{\circ}$ ) and its methyl ester (Metvix ${ }^{\circ}$ ) and porfimer sodium (Photofrin ${ }^{\circ}$ ). There are a wide range of PS still in pre-clinical and clinical trials $[25,26]$.

Porphyrins are highly conjugated heterocyclic tetrapyrroles that were first identified as having photodynamic properties in the 1970s [27, 28]. A porphyrin PS (5-[Aminobutyl- $N$ oxycarbonyl)phenyl]phenyl]-10,15,20-tris( $N$-methyl-4-pyridinium) porphyrin trichloride) plus light irradiation was able to reduce cell survival and prevent colony forming in prostate epithelial cells at concentrations of $>8.75 \mu \mathrm{M}$ [29]. The porphyrins TTP (5,10,15,20-tetra-p-tolyl porphyrin) and THNP $\left(5,10,15,20\right.$-tetra-p-naphthyl-porphyrin) after a light irradiation dose of $4.5 \mathrm{~J} / \mathrm{cm}^{2}$ were able to cause cell death in a human melanoma cell line in a concentration dependent manner [26]. The main disadvantage of PDT is the low selectivity of PS to their target, which can lead to damage to surrounding normal tissue and sustained skin photosensitivity [17]. In an attempt to overcome this research in PDT in oncology has focused on developing PS's conjugated to tumour targeted biological molecules [20]. Porphyrins have been successfully conjugated to a variety of biomolecules including mAbs [18, 30, 31], lipoproteins [32, 
33] and nanoparticles [34] which allowed for more targeted delivery of PS, and therefore a more specific tissue response with limited damage to normal tissue. A number of porphyrins have been developed that conjugate to biomolecules under mild conditions through direct reaction with lysine residues [18, $35,36]$.

The two primary amines, cysteine and lysine, at the N-terminal of duramycin offer potential sites for conjugation without interference with duramycin's binding site [3]. Using this theory a number of duramycin conjugates have been developed to take advantage of PE as a possible selective molecular probe. Fluorescent duramycin conjugates have been used to successfully target and image the lymphoma cancer cell line U937 [4], cancer derived microparticles [16], prostate tumour endothelium in rats [1] and the endothelium of aortic flow dividers [37]. Duramycin has been radiolabelled with gadolinium [3] and technetium-99m where it was used to image cell death in a rat model of acute myocardial infarction [38]. In this proof of concept study we conjugated duramycin to a porphyrin based photosensitiser and assessed its ability to bind to cancer cell surface PE. We also examined its cytotoxic activity on ovarian and pancreatic cancer cell lines following irradiation with visible light. 


\section{Materials and Methods}

\subsection{Cell Culture}

The cancer cell lines AsPC-1 and MIA PaCa-2 were purchased from the American Type Culture Collection (UK). The cancer cell lines A2780 and SK-OV-3 were purchased from the European Collection of Cell Cultures (UK). All cells were grown using distributors' instructions. All cells were cultured in either IMDM, McCoy's 5a Medium Modified or RPMI (Lonza, UK) substituted with 10\% FBS (15\% for McCoy's 5a Medium Modified) (Bio-Sera, UK) and (v/v); 100 units $/ \mathrm{mL}$ penicillin, $100 \mu \mathrm{g} / \mathrm{mL}$ streptomycin (P/S) (Lonza, UK). All serum was filtered using a $0.2 \mu \mathrm{M}$ syringe filter prior to addition to media. When not in use all media was stored between $4-6{ }^{\circ} \mathrm{C}$. All cells were incubated at $37{ }^{\circ} \mathrm{C}$ in a $5 \% \mathrm{CO}_{2}$ atmosphere. Cells were cultured in tissue culture flasks (Sarstedt, UK) and removed via scraping when cells were $70-90 \%$ confluent.

\subsection{Conjugation of Porphyrin to Duramycin}

A solution of duramycin (Sigma-Aldrich, UK, $10 \mathrm{mg}, 4.97 \times 10^{-3} \mathrm{mmol}$ ) in DMSO $(2 \mathrm{~mL}$ ) plus trimethylamine was treated with 5-[4-(N-succinimidyloxycarbonyl)phenyl]-10,15,20-tris(4-methylpyridinium)porphyrin trichloride [39] $\left(8 \mathrm{mg}, 9.94 \times 10^{-3} \mathrm{mmol}\right)$ and the resulting solution was mixed on a rotating shaker at room temperature for 24 hours. The crude material was recovered by addition of dichloromethane ( 5 $\mathrm{mL}$ ) and filtration through paper. The solid was dissolved in $1 \mathrm{~mL}$ of $0.1 \%$ aqueous trifluoroacetic acid (TFA) and the 1:1 porphyrin/duramycin conjugate was isolated by semi-preparative HPLC and analysed by electron ionising mass spectrometry (ESI-MS) (section 2.3). Recovery of $4.8 \mathrm{mg}$ of conjugate was achieved equating to $34.4 \%$ yield. An unconjugated, "capped" porphyrin was used as a control in which the NHS ester group used for conjugation was reacted with butylamine to eliminate any non-specific conjugation [29]. All photosensitiser containing compounds were kept, protected from light, at $-20^{\circ} \mathrm{C}$. Final concentrations of the re-suspended lyophilised powder of the conjugate and "capped" control were determined using UV-visible spectrophotometry.

\subsection{Analyses and Purification of Duramycin-Porphyrin Conjugate}

RP-HPLC-PDA analyses were performed on an Agilent 1200 HPLC system (Agilent, Germany) equipped with a G1312B BinPump SL, G13798 degasser, G1367D HiP ALS SL plus autosampler, a G1316B column compartment (set at $35^{\circ} \mathrm{C}$ ), and a $\mathrm{G} 1315 \mathrm{C}$ diode array detector (acquisition rate, $80 \mathrm{~Hz}$; scan rate: 380 $600 \mathrm{~nm}$, step: $1 \mathrm{~nm}$ ), using a Gemini C18 column, $5 \mu, 150 \times 4.6 \mathrm{~mm}, 110 \AA ̊$ column (Phenomenex, UK), equipped with a SecurityGuard C18 (ODS) $4 \times 3.0 \mathrm{~mm}$ ID guard column (Phenomenex, UK). The injection volume was $20 \mu \mathrm{L}$, and the flow rate was $1 \mathrm{~mL} / \mathrm{min}$. Mobile phase consisted of a mixture of $0.1 \%$ TFA in deionised water (18.2 M $\Omega$, Elga Purelab Ultra ULXXXGEM2), solvent $A$, and $0.1 \%$ TFA in HPLC-grade acetonitrile, solvent $B$. The gradient for the elution was as follows: $0-2 \mathrm{~min}, 5 \% \mathrm{~B}$; $2-7 \mathrm{~min}, \mathrm{~B}$ to $95 \%$; 7$12 \mathrm{~min}, 95 \% \mathrm{~B} ; 12-12.1 \mathrm{~min}, \mathrm{~B}$ to $5 \%$. Duramycin $R_{t}=7.32$, porphyrin $R_{t}=7.01$, conjugate $R_{t}=6.20 \mathrm{~min}$ (See supplementary figure S-1). RP-HPLC purifications were carried out on a Jasco HPLC system equipped with a PU-1580 LC pumps, HG-1580 degasser, AS-1555 autosampler and MD-1515 array UVvisible detector, using a Luna C18, $5 \mu, 250 \times 10 \mathrm{~mm}, 110 \AA$ (Phenomenex, UK), at a flow rate of 2.5 $\mathrm{mL} / \mathrm{min}$. Mobile phase consisted of a mixture of $0.1 \%$ TFA in deionised water (18.2 M $\Omega$, Elga Purelab Ultra ULXXXGEM2), solvent $A$, and $0.1 \%$ TFA in HPLC-grade acetonitrile, solvent $B$. The gradient for the elution was as follows: $0-8.5 \mathrm{~min}, 5 \%$ to $51 \% \mathrm{~B} ; 8.5-13 \mathrm{~min}, 51 \% \mathrm{~B} ; 13-14 \mathrm{~min}, 51$ to $95 \% \mathrm{~B} ; 14-18 \mathrm{~min}$, $95 \% \mathrm{~B}, 18-18.1 \mathrm{~min}, 95$ to $5 \% \mathrm{~B}$. Conjugate $\mathrm{R}_{\mathrm{t}}=6.20 \mathrm{~min}$ (See supplementary figure S-1). Q-TOF-MS data 
were acquired in positive mode scanning from 400 to $3000 \mathrm{~m} / \mathrm{z}$ with and without auto MS/MS fragmentation. Ionisation was achieved with an Agilent JetStream electrospray source and infused internal reference masses. Agilent 6540 Q-TOF-MS parameters: gas temperature, $325^{\circ} \mathrm{C}$; drying gas, 10 $\mathrm{L} / \mathrm{min}$; and sheath gas temperature, $400{ }^{\circ} \mathrm{C}$. ESI-MS (+): $675.66\left[\left(\mathrm{M}+4 \mathrm{H}^{+}\right) / 4\right]^{4+}(\exp : 675.67)$. Conjugate $\mathrm{R}_{\mathrm{t}}$ $=7.34$ (see supplementary figure S-2).

\subsection{Flow Cytometric Detection of Phosphatidylethanolamine}

Cells $\left(1 \times 10^{5}\right)$ were re-suspended in $25 \mu \mathrm{l}$ PBS and added to a $5 \mathrm{~mL}$ polypropylene tube (Sarstedt, UK). Duramycin-porphyrin conjugate $(5 \mu \mathrm{l})$ at required concentration was added to the tubes and incubated at room temperature in the dark for 30 minutes. Cells were washed with PBS, centrifuged at $320 \mathrm{~g}$ for 3 minutes and re-suspended in $300 \mu \mathrm{l}$ PBS and then analysed using a BD FACScalibur (BD Biosciences, UK).

\subsection{Flow Cytometric Analysis of Forward Scatter and Side Scatter}

Analysis of forward scatter (FSC) and side scatter (SSC) data was performed using BD CellQuest Pro software $^{\mathrm{TM}}$ version 5.1 (BD Biosciences, UK) after cells were processed using the method described above. FSC and SSC data using the unconjugated duramycin was collected as part of a study to determine the effect of duramycin on cell viability over a 2 hour time course (unpublished data). These cells were processed using a flow cytometric cell viability analysis method described previously [15]. Briefly cells $\left(2 \times 10^{5}\right)$ were incubated with an appropriate concentration of unconjugated duramycin at room temperature in the dark for 30 minutes and analysed using Annexin V: FITC Apoptosis Detection Kit I (BD Biosciences, UK).

\subsection{Competition Binding Assays}

Cells $\left(2 \times 10^{5}\right)$ were re-suspended in $40 \mu \mathrm{PBS}$ and added to a $5 \mathrm{~mL}$ polypropylene tube (Sarstedt, UK). Duramycin-porphyrin conjugate $(10 \mu \mathrm{l}$, final concentration $50 \mu \mathrm{M})$ was added to the tubes and incubated at room temperature in the dark for 5 minutes. The cells were washed with PBS, centrifuged at $320 \mathrm{~g}$ for 3 minutes and re-suspended in $40 \mu \mathrm{l}$ PBS except for the 0 minute tube which was resuspended with $300 \mu \mathrm{l}$ PBS and analysed by flow cytometry. Unconjugated duramycin (10 $\mu$, final concentration $50 \mu \mathrm{M})$ was added to the remaining tubes. After appropriate incubation time $(2,5,15$ or 30 minutes) $250 \mu \mathrm{l}$ PBS was added to the tubes and the cells analysed using flow cytometry.

\subsection{Photodynamic Light Treatment Cells}

$\left(8 \times 10^{5}\right)$ in serum free medium were added to $5 \mathrm{~mL}$ polypropylene tubes (Sarstedt, UK) containing duramycin-porphyrin conjugate at required concentration $(0-10 \mu \mathrm{M})$ and incubated in the dark at $37^{\circ} \mathrm{C}$ in a $5 \% \mathrm{CO}_{2}$ atmosphere for 5 minutes. Cells were then washed with $3 \mathrm{~mL}$ medium so as to remove any unbound conjugate and centrifuged at $300 \mathrm{~g}$ for 10 minutes and re-suspended in $1 \mathrm{~mL}$ medium. Cells $(8 \mathrm{x}$ $10^{4}$ ) were then plated into 96 well plates and incubated in the dark at $37{ }^{\circ} \mathrm{C}$ in a $5 \% \mathrm{CO}_{2}$ atmosphere for 5 minutes. The PDT light supply (9x14 LED Array, wavelength 620-660 nm) was allowed to stabilise and irradiance reading taken using a R203 Macam radiometer (Irradian Ltd. UK). After incubation one plate was irradiated with a light fluence of $7.5 \mathrm{~J} / \mathrm{cm}^{2}$ red light while the other served as the dark control (i.e. not irradiated). After light treatment $5 \mu \mathrm{l} \mathrm{FBS}$ was added to each well and the plates incubated at $37{ }^{\circ} \mathrm{C}$ in a $5 \% \mathrm{CO}_{2}$ atmosphere for 24 hours.

\subsection{Cell Proliferation Assay}


After 24 hours incubation $10 \mu \mathrm{l}$ MTT (3-[4,5-dimethylthiazol-2-yl]-2,5- diphenyltetrazolium bromide; thiazolyl blue) (Sigma-Aldrich, UK) (12 mM solution in PBS) was added to each well of the 96 well plates. The plates were incubated at $37{ }^{\circ} \mathrm{C}$ in a $5 \% \mathrm{CO}_{2}$ atmosphere for 4 hours and then the crystals were dissolved by adding $150 \mu \mathrm{l}$ of acid-alcohol mixture $(0.04 \mathrm{~mol} / \mathrm{L} \mathrm{HCl}$ in absolute 2-propanol). The plates were then analysed at $570 \mathrm{~nm}$ using a Biotek ELX800 Universal Microplate Reader (Corgenix Ltd., UK). Percentage cell survival was expressed relative to control values. 


\section{Results}

\subsection{Phosphatidylethanolamine Detection}

The duramycin-porphyrin conjugate (Figure 1) was able to detect cell surface PE expression on the ovarian cancer cell lines, A2780 and SK-OV-3, and the pancreatic cancer cell lines, AsPC-1 and MIA PaCa2 using flow cytometry. $\log _{10}$ median PE fluorescence ( $635 \mathrm{~nm}$ laser, FL-4 flow cytometer channel) was used to express levels of detected PE. The duramycin-porphyrin conjugate detected levels of PE in a concentration dependent manner on all 4 cell lines (Figure 2). Optimal PE detection was seen using 1 $\mathrm{mM}$ conjugate. As an average of all 4 cell lines the $\log _{10}$ median PE fluorescence increased from $0.17 \pm 0.007$ when detected with $1 \mu \mathrm{M}$ conjugate to $2.21 \pm 0.192$ when detected with $1 \mathrm{mM}$ conjugate. The duramycin-porphyrin conjugate was detectable through the flow cytometer's FL-1 channel (flow cytometer's $488 \mathrm{~nm}$ laser) due to fluorescence of the porphyrin component of the conjugate at this wavelength.

\subsection{Competitive Binding for Phosphatidylethanolamine}

To investigate whether the binding ability of the duramycin-porphyrin conjugate to PE was affected by the conjugation procedure a competition assay was performed using flow cytometry. The unconjugated duramycin was unable to compete for cell surface PE on the cancer cell lines which had been preincubated with duramycin-porphyrin conjugate (Figure 3). The median PE fluorescence (FL-4 channel) of A2780 and MIA PaCa-2 was determined, using the pre-bound conjugate, as $10.9 \pm 0.75$ and $16.7 \pm 5.9$, respectively. Duramycin was incubated with the cancer cell lines for $0,2,5,15$ and 30 minutes to allow time to potentially displace the conjugate and competitively bind to PE. The median PE fluorescence of MIA PaCa-2 remained constant, within standard deviation, at each interval across the 30 minute time course. The median PE fluorescence of the A2780 however increased over time to the maximum of $12.8 \pm 0.16$ at 30 minutes. The unaffected binding affinity of the conjugate for PE after ligation to porphyrin provides evidence that the conjugation method used in this study does not disrupt PE binding. Alternatively, the assay was performed with the unconjugated duramycin pre-bound and the conjugate as the competing species, similarly over a 30 minute time course. The median PE fluorescence (FL-1 channel) detected remained constant at $8.3 \pm 1.8$ for A2780 and $11.7 \pm 1.4$ for MIA PaCa-2 over the 30 minutes. However it cannot be certain that the FL-1 signal originated from the unconjugated duramycin (labelled with a tertiary FITC antibody detected at $488 \mathrm{~nm}$ ) as the duramycin-porphyrin conjugate signal is also detectable on this channel.

\subsection{Effect on Cell Size and Morphology}

We have previously reported the effect that unconjugated duramycin has on the morphology of A2780, AsPC-1, MIA PaCa-2 and SK-OV-3 with relation to an increase in cell size (FSC) and internal cell complexity/ granularity (SSC) [15]. FSC and SSC data collected via flow cytometry was analysed after the same 4 cancer cell lines were treated with the duramycin-porphyrin conjugate at concentrations between $1 \mu \mathrm{M}$ and $1 \mathrm{mM}$ (Figure 4). A2780 and SK-OV-3 increased in SSC when treated with $1 \mathrm{mM}$ conjugate and AsPC-1 and MIA PaCa-2 increased in SSC when treated with $>250 \mu \mathrm{M}$. A2780 and MIA PaCa-2 showed a slight increase in FSC when treated with $1 \mathrm{mM}$ duramycin-porphyrin conjugate.

\subsection{Photodynamic Cytotoxicity Assays}


The duramycin-porphyrin conjugate was used in the photodynamic treatment of the cancer cell lines A2780, AsPC-1, MIA PaCa-2 and SK-OV-3. The irradiated duramycin-porphyrin conjugate was able to reduce the cell survival of the $\mathrm{A} 2780$ cancer cells at concentrations $>2.5 \mu \mathrm{M}$ (Figure 5a). A significant difference in reduction in cell survival between the irradiated and non-irradiated conjugate treated cells occurred at $2.5 \mu \mathrm{M}$ where cell survival was 53.7 and $74.4 \%$, respectively. The conjugate at the highest concentration of $10 \mu \mathrm{M}$ was able to reduce cell survival to $3.2 \%$. The unconjugated duramycin caused a slight reduction in cell survival at concentrations $>5 \mu \mathrm{M}$. The non-irradiated "capped" control porphyrin (porphyrin with no duramycin) showed no cytotoxicity. The irradiated "capped" control porphyrin however showed similar levels of cytotoxicity as the irradiated conjugate treated cells at concentrations $>5 \mu \mathrm{M}$. MIA PaCa-2 cells showed less sensitivity to photodynamic light treatment than A2780. For conjugate treated MIA PaCa-2 cells the significant difference in reduction of cell survival between the irradiated and non-irradiated conditions occurred at $5 \mu \mathrm{M}$ (Figure $5 \mathrm{~b}$ ). At $10 \mu \mathrm{M}$ cell survival was reduced to $36.3 \%$. The non-irradiated conjugate and "capped" control porphyrin showed no cytotoxicity. The irradiated "capped" control porphyrin reduced cell survival slightly at the highest concentration of $10 \mu \mathrm{M}$. Reduction in cell survival of MIA PaCa-2 in conjugate treated cells was not significantly different to unconjugated duramycin treated cells. At a concentration of $10 \mu \mathrm{M}$ the cell survival for the irradiated and non-irradiated unconjugated duramycin was $40.3 \%$ and $43.5 \%$, respectively. The reaction to photodynamic light treatment was similar in the cancer cell lines AsPC-1 (Figure 5c) and SK-OV-3 (Figure $5 \mathrm{~d}$ ). Both of these cell lines showed a slight reduction in cell survival when treated with $1.25 \mu \mathrm{M}$ irradiated conjugate and a significant reduction at concentrations $>2.5 \mu \mathrm{M}$. The cell survival of nonirradiated AsPC-1 cells treated with $2.5 \mu \mathrm{M}$ conjugate was $83.4 \%$ compared to irradiated cells at $6.3 \%$. For SK-OV-3 cell survival was $91.2 \%$ and $11.7 \%$ for the non-irradiated and irradiated conditions, respectively. At the highest concentration of $10 \mu \mathrm{M}$ duramycin-porphyrin conjugate reduced cell survival to $1.83 \%$ in AsPC-1 and $2.76 \%$ in SK-OV-3. The non-irradiated conjugate showed dark toxicity at concentrations $>5 \mu \mathrm{M}$ and the irradiated "capped" control porphyrin control slightly reduced cell survival at $10 \mu \mathrm{M}$ for both cancer cell lines. Unconjugated duramycin showed a cytotoxic effect in a concentration dependent manner for both AsPC-1 and SK-OV-3. For example at $10 \mu \mathrm{M}$ the irradiated unconjugated duramycin reduced cell survival to $48.7 \%$ in AsPC-1 and $60.6 \%$ in SK-OV-3. Indeed unconjugated duramycin reduced cell survival in a concentration dependent manner in all 4 cell lines. However this is to be expected due to the cytotoxic abilities of unconjugated duramycin at these concentrations as seen previously [15]. 


\section{Discussion}

Conjugation of tetrapyrroles to peptides can be chemically challenging due to the requirement of bringing the two moieties together regio-selectively whilst maintaining their separate functionalities [36].

In this study conjugation occurred by the formation of a covalent amide bond between an $\mathrm{N}$ hydroxysuccinimide (NHS) ester of the porphyrin and the $\varepsilon$-amino group on the lysine residue at duramycin's N-terminal. The conjugation of the porphyrin to duramycin at this chosen location should minimise interference with the PE binding site [3]. A number of biological molecules conjugated to porphyrin through lysine residues have been shown to retain their antimicrobial function [39-41]. The scFv antibody fragment LAG-3 when conjugated through its lysine residues to a porphyrin PS was shown to bind to the colorectal cancer cell line Caco-2 and effectively induce cell death following $15 \mathrm{~J} / \mathrm{cm}^{2}$ light treatment [18]. In this study the duramycin-porphyrin conjugate was used to detect cell surface PE expression on the 4 cancer cell lines A2780, AsPC-1, MIA PaCa-2 and SK-OV-3 via flow cytometry. In this way the conjugate was tested to see whether the duramycin component's ability to bind the ethanolamine head group of PE had been altered during conjugation. It was also assessed herein whether the porphyrin had retained its fluorescent properties. The conjugate detected PE expression on all 4 cell lines and was detected in a concentration dependent manner thus verifying the conjugates ability to bind its target and maintain detectable fluorescence. To further investigate whether the conjugate's PE binding ability was affected by the conjugation procedure a competition assay was performed via flow cytometry. Unconjugated duramycin did not have the ability to outcompete the conjugate for binding of cell surface PE. The median PE fluorescence detected remained constant for MIA PaCa-2 cells over the 30 minute time course and was seen to slightly increase for A2780.

We have previously reported that unconjugated duramycin has an effect on the FSC and SSC properties of cancer cell lines [15]. Duramycin has the ability to increase cell size (FSC) of AsPC-1 cells at $>50 \mu \mathrm{M}$ and increase cell granularity (SSC) of A2780, AsPC-1, MIA PaCa-2 and SK-OV-3 at $>200 \mu \mathrm{M}$. Necrotic cell death is associated with swelling of the cell followed by rapid release of intracellular content and an increase in granularity which have been linked to an increase in FSC and SSC, respectively [42]. An increase in SSC was seen to correlate with increased granularity in prostate cancer cells (LNCaP and PC3) [43]. Cells with an increased SSC in the renal proximal tubular epithelial cell line LLC-PK1 were identified as apoptotic by flow cytometry and those with an increased FSC as necrotic [44]. Heightened SSC was also seen in early apoptotic cells where condensation of the cell nucleus and cytoplasm during cell shrinkage lead to enhanced light refraction [45]. However it is important to state that morphological and cell size changes measured via light scatter should be considered as supportive rather than as definitive evidence of cell death. We have previously shown via confocal imaging that duramycin treated AsPC-1 cells lose cell membrane staining accompanied with an uptake of propidium iodide suggesting a loss in membrane integrity or cell death. An increase in cell size was also observed, which is indicative of cell swelling prior to cell death [15]. The duramycin-porphyrin conjugate also effected the FSC/ SSC properties of the ovarian and pancreatic cancer cell lines. FSC was increased in A2780 and MIA PaCa-2 when treated with $1 \mathrm{mM}$ conjugate and SSC increased in all 4 cell lines though AsPC-1 and MIA PaCa- 2 at $>250 \mu \mathrm{M}$ and A2780 and SK-OV-3 at $1 \mathrm{mM}$. The similar effects on FSC and SSC produced by duramycin and duramycin-porphyrin conjugate could provide additional evidence of duramycin's maintained functionality when conjugated to porphyrin. The higher concentration of conjugate required to exert 
this effect on the cell lines compared to duramycin alone is beneficial to PDT where minimal non-specific damage is a desired characteristic of any PS [25].

A number of studies in the literature have investigated the effect of PDT on ovarian and pancreatic cancer in a variety of models including cell lines [46], 3D cell culture [47-49], transplanted mice [50, 51] and Phase I/II human trials $[52,53]$. A benzoporphyrin derivative (BPD) at $0.25 \mu \mathrm{M}$ was able to reduce cell viability and volume in the human ovarian carcinoma cell line OVCAR5 and penetrate well through OVCAR5 3D cell culture $[47,48]$. In another study in which OVCAR5 cells were grown in a culture film a fibre optic delivery system was used where the PS (pheophorbide) and oxygen gas was delivered separately [49]. Good diffusion of the PS to cells beyond the reach of the probe tip was observed. Balb/C mice transplanted with the ovarian cancer cell line OVCAR3 where treated with an immunoconjugated PS and irradiated with in vivo results showing targeted treatment and minimal damage to the surrounding vasculature [50]. A pancreatic cell line panel showed the cancer cell line AsPC-1 was particularly sensitive to PDT. Treatment of this cell line with verteporfin at $250 \mathrm{nM}$ with a light dose of $10 \mathrm{~J} / \mathrm{cm}^{2}$ was effective enough to induce complete cell death [46]. Verteporfin has been used successfully in a Phase I/II trial against advanced pancreatic cancer where it accumulated quickly in the target tissue, induced necrotic cell death and had a fast clearance via excretion in bile [53].

In this study we used 2 ovarian and 2 pancreatic cancer cell lines to evaluate the cytotoxic extent of our newly developed PS, duramycin-porphyrin conjugate, taking advantage of duramycin's specificity for cell surface expressed PE. The duramycin-porphyrin conjugate was able to reduce cell survival of all 4 cancer cell lines after irradiation with a light dose of $7.5 \mathrm{~J} / \mathrm{cm}^{2}$ red light. The significant difference in cell survival between the non-irradiated and irradiated cells treated with the conjugate occurred at $2.5 \mu \mathrm{M}$ for A2780, AsPC-1 and SK-OV-3. MIA PaCa-2 exhibited less sensitivity to the PDT light treatment and a significant drop in cell survival occurred only when cells were treated with $5 \mu \mathrm{M}$ conjugate. Treatment with $10 \mu \mathrm{M}$ conjugate was effective enough to reduce cell survival to $<3.2 \%$ in A2780, AsPC-1 and SKOV-3. However cell survival in MIA PaCa-2 was only ever reduced to $36.3 \%$ at the highest concentration. Reduction in cell survival of MIA PaCa-2 in conjugate treated cells was not significantly different to unconjugated duramycin treated cells. The greater resistance to irradiation and the lack of increased cytotoxic effect of the conjugate over duramycin alone may suggest that MIA PaCa-2 cancer cells may not be a candidate for PDT using this PS. Out of the 2 pancreatic cancer cell lines used in this study MIA PaCa-2 is the less aggressive form. Samkoe et al. [51] discovered that aggressive, fast growing pancreatic cancer (AsPC-1) responded better to verteporfin PDT than the less aggressive cell line (PANC1 ) in transplanted mice. In their vascular occlusion experiments $40 \mathrm{~J} / \mathrm{cm}$ light dose was enough to induce complete necrosis in the tumours of AsPC-1 transplanted mice but not in PANC-1. They concluded that this difference in reaction to light treatment between cell lines could depend on tumour aggressiveness and other inherent biophysical properties. It has been observed in human trials that these differences in response to light treatment are of clinical importance where light dose can raise different reactions even in patients with the same type of malignancy [20,52].

The "capped" porphyrin control when irradiated reduced cell survival slightly in AsPC-1, SK-OV-3 and MIA PaCa-2 at $10 \mu \mathrm{M}$. In a recent study [29] this "capped" control porphyrin was used in PDT experiments against benign and malignant prostate cells to assess its cytotoxic potential. "Capped" porphyrin $>8.75 \mu \mathrm{M}$ was seen to induce necrosis and prevent colony forming in irradiated prostate cells. In the A2780 cancer cell line the capped porphyrin control produced similar levels of cytotoxicity as to that produced by the irradiated conjugate. An increased uptake and localisation of the "capped" 
porphyrin could potentially explain this increased sensitivity. However DNA damage in the prostate cells (suggesting localisation occurred in the nucleus) was induced after 1 hour incubation with the porphyrin [29]. This movement into the cell and localisation of the "capped" control porphyrin is unlikely to have occurred in the A2780 cells in the relatively short incubation of 5 minutes used in this study.

The differences in sensitivities to irradiation between cancer cell lines could potentially be explained by the cytoprotective mechanisms that cancer cells can employ to escape PDT induced cell death. Antioxidant molecules and detoxifying enzymes such as superoxide dismutase (SOD) present in cancer cells have been implicated in the protection against PDT effects [17]. Other cytoprotective mechanisms have been demonstrated to be induced by PDT itself including the i) initiation of stress-related transcription factors e.g. hypoxia inducible factor (HIF) and nuclear factor erythroid 2-related factor 2 (NRF2), ii) increased heat shock protein (HSP) levels e.g. elevated HSP60 and HSP70 have been seen to be inversely correlated with PDT sensitivity and iii) inhibition of NF-KB which can activate anti-apoptotic genes [17]. The literature reports at least some of these protective mechanisms are active in the ovarian and pancreatic cancer cell lines used in this study. An upregulation of HIF-1- $\alpha$, an important factor in tumour metastasis and progression, was seen to accompany the hypoxic state of A2780 tumours [54] and has also been observed in hypoxia induced MIA PaCa-2 cells [55] and following oxidative stressinduced ROS production in SK-OV-3 cells [56]. SK-OV-3 cells also have an upregulation of the antioxidant gene SOD2 [57] which could protect against harmful PDT effects. This ovarian cancer cell line has also been shown to have enhanced NF-KB activity, when stimulated by ROS, which lead to the activation of anti-apoptotic genes [58]. NRF2 is the principal transcription factor of many antioxidant and detoxification genes and is overexpressed in A2780 [59], SK-OV-3 [60] and AsPC-1 cells [61, 62] and can be induced in the presence of ROS especially in pancreatic cancer [62]. HSPs can bind oxidatively damaged proteins and play a role in pro-survival pathways [17]. HSP70 is overexpressed in MIA PaCa-2 cells [63] and is found in much higher quantities in tissue from patients with ovarian cancer than in normal ovarian tissue [64]. The effectiveness of PDT relies on an available and sustained oxygen supply to tissue, which may be reduced in hypoxic conditions [65]. A2780 xenografts in a murine model of ovarian cancer were found to be extremely hypoxic $(2.0 \pm 0.7 \mathrm{mmHg})$ when compared to RIF-1 xenografts $(7.8 \pm 1.4 \mathrm{mmHg})$; a typical hypoxic tumour model [54].

An important property of any good PS is a high intersystem crossing (ISC) yield i.e. a high possibility of conversion from the excited singlet state to the longer lived excited triplet state, from which energy transfer to ground state (triplet) oxygen occurs [20]. Tetrapyrroles, such as the porphyrin moiety used in this study, are very efficient at undergoing ISC [66]. The benefit of conjugating tetrapyrroles with peptides is that their small size allows for good tissue penetration and usually renders them nonimmunogenic [36]. An advantage of the type of porphyrin used in this study is that the conjugation procedure does not produce reactive intermediates or by-products [18, 35]. This porphyrin has previously been shown to exhibit antibacterial properties, be an efficient cytotoxic after 5 minutes irradiation and be stable against photodegradation [39]. The duramycin-porphyrin conjugate reported here is an effective PS for the targeted PDT treatment of cancer cells. With a relatively low (in vitro) cytotoxic concentration of $2.5 \mu \mathrm{M}$ the conjugate offers benefits over unconjugated duramycin induced cell death. At these low concentrations duramycin does not cause necrosis but can reliably bind cell surface expressed PE [15]. Unconjugated duramycin has been shown to bind PE expressed on the tumour vasculature [1]. Through the possibility of targeted irradiance the duramycin-porphyrin conjugate could allow for specific death of the tumour and therefore reduce the risk of collateral 
damage to surrounding normal tissue. Photodynamic effect usually occurs very close to the localisation of the PS [17] and when the PS's binding site is the plasma membrane necrotic cell death can very rapidly follow irradiation [67]. As the duramycin-porphyrin conjugate binds to cancer cell membranes it is possible that cell death occurs via rapid necrosis which may reduce the risk of PDT-induced cytoprotective mechanisms.

PDT is evidently an effective anti-cancer therapy though only a limited number of PS have been approved by the FDA and EU for use in the clinical setting $[20,26]$. For PDT to be better utilised as a treatment strategy the development of PS that possess selectivity for binding sites overexpressed or enhanced on a wide range of cancer types is needed. In this proof of concept study we have shown that the PS duramycin-porphyrin conjugate retained good binding affinity for its target and, following irradiation, reduced cell survival of pancreatic and ovarian cancer cell lines in a concentration dependent manner. As we have previously shown, duramycin has the ability to bind to cell surface expressed PE on a range of cancer cell lines [15], and so we hypothesise that this PS could potentially be used against a number of different cancer types. Further work with duramycin-porphyrin conjugate in the in vivo

environment could potentially confirm this conjugate as a promising new PS in the PDT treatment of cancer.

\section{Conflict(s) of Interest}

The authors declare that they have no conflicts of interest with the contents of this article. 


\section{References}

1. Stafford, J.H. and P.E. Thorpe, Increased Exposure of Phosphatidylethanolamine on the Surface of Tumor Vascular Endothelium. Neoplasia, 2011. 13(4): p. 299-IN2.

2. Zimmermann, N., S. Freund, A. Fredenhagen, and G. Jung, Solution structures of the lantibiotics duramycin B and C. European Journal of Biochemistry, 1993. 216(2): p. 419-428.

3. Zhao, M., Lantibiotics as probes for phosphatidylethanolamine. Amino Acids, 2011. 41(5): p. 1071-1079.

4. Aoki, Y., T. Uenaka, J. Aoki, M. Umeda, and K. Inoue, A novel peptide probe for studying the transbilayer movement of phosphatidylethanolamine. Journal of biochemistry, 1994. 116(2): $p$. 291-297.

5. Hayashi, F., K. Nagashima, Y. Terui, Y. Kawamura, K. Matsumoto, and H. Itazaki, The Structure Of PA48009: The Revised Structure. The Journal of Antibiotics, 1990. 43(11): p. 1421-1430.

6. Fadeel, B. and D. Xue, The ins and outs of phospholipid asymmetry in the plasma membrane: roles in health and disease. Crit Rev Biochem Mol Biol, 2009. 44(5): p. 264-77.

7. van Meer, G., D.R. Voelker, and G.W. Feigenson, Membrane lipids: where they are and how they behave. Nat Rev Mol Cell Biol, 2008. 9(2): p. 112-24.

8. Daleke, D.L., Phospholipid flippases. J Biol Chem, 2007. 282(2): p. 821-5.

9. Sahu, S.K., S.N. Gummadi, N. Manoj, and G.K. Aradhyam, Phospholipid scramblases: an overview. Arch Biochem Biophys, 2007. 462(1): p. 103-14.

10. Zwaal, R.F.A. and A.J. Schroit, Pathophysiologic Implications of Membrane Phospholipid Asymmetry in Blood Cells. Blood, 1997. 89(4): p. 1121-1132.

11. Emoto, K., N. Toyama-Sorimachi, H. Karasuyama, K. Inoue, and M. Umeda, Exposure of Phosphatidylethanolamine on the Surface of Apoptotic Cells. Experimental Cell Research, 1997. 232(2): p. 430-434.

12. Zwaal, R.F.A., P. Comfurius, and E.M. Bevers, Lipid-protein interactions in blood coagulation. Biochimica et Biophysica Acta (BBA) - Reviews on Biomembranes, 1998. 1376(3): p. 433-453.

13. Falls, L.A., B. Furie, and B.C. Furie, Role of Phosphatidylethanolamine in Assembly and Function of the Factor IXa-Factor VIIla Complex on Membrane Surfacest. Biochemistry, 2000. 39(43): p. 13216-13222.

14. Yates, K.R., J. Welsh, N.O. Udegbunam, J. Greenman, A. Maraveyas, and L.A. Madden, Duramycin exhibits antiproliferative properties and induces apoptosis in tumour cells. Blood Coagul Fibrinolysis, 2012. 23(5): p. 396-401.

15. Broughton, L.J., C. Crow, A. Maraveyas, and L.A. Madden, Duramycin-induced calcium release in cancer cells. Anti-Cancer Drugs, 2016. 27(3): p. 173-182.

16. Larson, M.C., J.E. Woodliff, C.A. Hillery, T.J. Kearl, and M. Zhao, Phosphatidylethanolamine is externalized at the surface of microparticles. Biochimica et Biophysica Acta (BBA) - Molecular and Cell Biology of Lipids, 2012. 1821(12): p. 1501-1507.

17. Agostinis, P., K. Berg, K.A. Cengel, T.H. Foster, A.W. Girotti, S.O. Gollnick, S.M. Hahn, M.R. Hamblin, A. Juzeniene, D. Kessel, M. Korbelik, J. Moan, P. Mroz, D. Nowis, J. Piette, B.C. Wilson, and J. Golab, Photodynamic therapy of cancer: an update. CA Cancer J Clin, 2011. 61(4): p. 25081.

18. Staneloudi, C., K.A. Smith, R. Hudson, N. Malatesti, H. Savoie, R.W. Boyle, and J. Greenman, Development and characterization of novel photosensitizer : scFv conjugates for use in photodynamic therapy of cancer. Immunology, 2007. 120(4): p. 512-7.

19. Korbelik, M., PDT-associated host response and its role in the therapy outcome. Lasers Surg Med, 2006. 38(5): p. 500-8. 
20. Zhu, T.C. and J.C. Finlay, The role of photodynamic therapy (PDT) physics. Medical Physics, 2008. 35(7): p. 3127.

21. Nestor, M.S., M.H. Gold, A.N. Kauvar, A.F. Taub, R.G. Geronemus, E.C. Ritvo, M.P. Goldman, D.J. Gilbert, D.F. Richey, T.S. Alster, R.R. Anderson, D.E. Bank, A. Carruthers, J. Carruthers, D.J. Goldberg, C.W. Hanke, N.J. Lowe, D.M. Pariser, D.S. Rigel, P. Robins, J.M. Spencer, and B.D. Zelickson, The use of photodynamic therapy in dermatology: results of a consensus conference. J Drugs Dermatol, 2006. 5(2): p. 140-54.

22. Braathen, L.R., R.M. Szeimies, N. Basset-Seguin, R. Bissonnette, P. Foley, D. Pariser, R. Roelandts, A.M. Wennberg, C.A. Morton, and D. International Society for Photodynamic Therapy in, Guidelines on the use of photodynamic therapy for nonmelanoma skin cancer: an international consensus. International Society for Photodynamic Therapy in Dermatology, 2005. J Am Acad Dermatol, 2007. 56(1): p. 125-43.

23. Jerjes, W., T. Upile, S. Akram, and C. Hopper, The surgical palliation of advanced head and neck cancer using photodynamic therapy. Clin Oncol (R Coll Radiol), 2010. 22(9): p. 785-91.

24. Wolfsen, H.C., Carpe luz--seize the light: endoprevention of esophageal adenocarcinoma when using photodynamic therapy with porfimer sodium. Gastrointest Endosc, 2005. 62(4): p. 499503.

25. Nowis, D., M. Makowski, T. Stoklosa, M. Legat, T. Issat, and J. Golab, Direct tumor damage mechanisms of photodynamic therapy. Acta Biochim Pol, 2005. 52(2): p. 339-52.

26. Baldea, I., R.M. Ion, D.E. Olteanu, I. Nenu, D. Tudor, and A.G. Filip, Photodynamic therapy of melanoma using new, synthetic porphyrins and phthalocyanines as photosensitisers - $a$ comparative study. Clujul Med, 2015. 88(2): p. 175-80.

27. Spikes, J.D., Porphyrins and related compounds as photodynamic sensitizers. Ann N Y Acad Sci, 1975. 244: p. 496-508.

28. Yang, X., P. Palasuberniam, D. Kraus, and B. Chen, Aminolevulinic Acid-Based Tumor Detection and Therapy: Molecular Mechanisms and Strategies for Enhancement. Int J Mol Sci, 2015. 16(10): p. 25865-80.

29. Frame, F.M., H. Savoie, F. Bryden, F. Giuntini, V.M. Mann, M.S. Simms, R.W. Boyle, and N.J. Maitland, Mechanisms of growth inhibition of primary prostate epithelial cells following gamma irradiation or photodynamic therapy include senescence, necrosis, and autophagy, but not apoptosis. Cancer Med, 2016. 5(1): p. 61-73.

30. Vrouenraets, M.B., G.W. Visser, F.A. Stewart, M. Stigter, H. Oppelaar, P.E. Postmus, G.B. Snow, and G.A. van Dongen, Development of meta-tetrahydroxyphenylchlorin-monoclonal antibody conjugates for photoimmunotherapy. Cancer Res, 1999. 59(7): p. 1505-13.

31. Del Governatore, M., M.R. Hamblin, E.E. Piccinini, G. Ugolini, and T. Hasan, Targeted photodestruction of human colon cancer cells using charged 17.1A chlorin e6 immunoconjugates. Br J Cancer, 2000. 82(1): p. 56-64.

32. Hamblin, M.R. and E.L. Newman, Photosensitizer targeting in photodynamic therapy. II. Conjugates of haematoporphyrin with serum lipoproteins. J Photochem Photobiol B, 1994. 26(2): p. 147-57.

33. Schmidt-Erfurth, U., H. Diddens, R. Birngruber, and T. Hasan, Photodynamic targeting of human retinoblastoma cells using covalent low-density lipoprotein conjugates. $\mathrm{Br} J$ Cancer, 1997. 75(1): p. 54-61.

34. Vega, D.L., P. Lodge, and J.L. Vivero-Escoto, Redox-Responsive Porphyrin-Based Polysilsesquioxane Nanoparticles for Photodynamic Therapy of Cancer Cells. Int J Mol Sci, 2016. 17(1). 
35. Sutton, J.M., O.J. Clarke, N. Fernandez, and R.W. Boyle, Porphyrin, chlorin, and bacteriochlorin isothiocyanates: useful reagents for the synthesis of photoactive bioconjugates. Bioconjug Chem, 2002. 13(2): p. 249-63.

36. Giuntini, F., C.M. Alonso, and R.W. Boyle, Synthetic approaches for the conjugation of porphyrins and related macrocycles to peptides and proteins. Photochem Photobiol Sci, 2011. 10(5): p. 75991.

37. Li, Z., C.W. Wells, P.E. North, S. Kumar, C.B. Duris, J.A. Mclntyre, and Z. Ming, Phosphatidylethanolamine at the luminal endothelial surface--implications for hemostasis and thrombotic autoimmunity. Clin Appl Thromb Hemost, 2011. 17(2): p. 158-63.

38. Zhao, M., Z. Li, and S. Bugenhagen, $99 \mathrm{mTc}$-labeled duramycin as a novel phosphatidylethanolamine-binding molecular probe. J Nucl Med, 2008. 49(8): p. 1345-52.

39. Tome, J.P., M.G. Neves, A.C. Tome, J.A. Cavaleiro, M. Soncin, M. Magaraggia, S. Ferro, and G. Jori, Synthesis and antibacterial activity of new poly-S-lysine-porphyrin conjugates. J Med Chem, 2004. 47(26): p. 6649-52.

40. Soukos, N.S., L.A. Ximenez-Fyvie, M.R. Hamblin, S.S. Socransky, and T. Hasan, Targeted Antimicrobial Photochemotherapy. Antimicrobial Agents and Chemotherapy, 1998. 42(10): p. 2595-2601.

41. Polo, L., A. Segalla, G. Bertoloni, G. Jori, K. Schaffner, and E. Reddi, Polylysine-porphycene conjugates as efficient photosensitizers for the inactivation of microbial pathogens. J Photochem Photobiol B, 2000. 59(1-3): p. 152-8.

42. Dive, C., C.D. Gregory, D.J. Phipps, D.L. Evans, A.E. Milner, and A.H. Wyllie, Analysis and discrimination of necrosis and apoptosis (programmed cell death) by multiparameter flow cytometry. Biochimica et Biophysica Acta (BBA) - Molecular Cell Research, 1992. 1133(3): p. 275285.

43. Haynes, M.K., J.J. Strouse, A. Waller, A. Leitao, R.F. Curpan, C. Bologa, T.I. Oprea, E.R. Prossnitz, B.S. Edwards, L.A. Sklar, and T.A. Thompson, Detection of intracellular granularity induction in prostate cancer cell lines by small molecules using the HyperCyt high-throughput flow cytometry system. J Biomol Screen, 2009. 14(6): p. 596-609.

44. Healy, E., M. Dempsey, C. Lally, and M.P. Ryan, Apoptosis and necrosis: mechanisms of cell death induced by cyclosporine A in a renal proximal tubular cell line. Kidney Int, 1998. 54(6): p. 195566.

45. Wlodkowic, D., W. Telford, J. Skommer, and Z. Darzynkiewicz, Apoptosis and beyond: cytometry in studies of programmed cell death. Methods Cell Biol, 2011. 103: p. 55-98.

46. Celli, J.P., N. Solban, A. Liang, S.P. Pereira, and T. Hasan, Verteporfin-based photodynamic therapy overcomes gemcitabine insensitivity in a panel of pancreatic cancer cell lines. Lasers Surg Med, 2011. 43(7): p. 565-74.

47. Rizvi, I., S. Anbil, N. Alagic, J. Celli, L.Z. Zheng, A. Palanisami, M.D. Glidden, B.W. Pogue, and T. Hasan, PDT dose parameters impact tumoricidal durability and cell death pathways in a 3D ovarian cancer model. Photochem Photobiol, 2013. 89(4): p. 942-52.

48. Anbil, S., I. Rizvi, J.P. Celli, N. Alagic, B.W. Pogue, and T. Hasan, Impact of treatment response metrics on photodynamic therapy planning and outcomes in a three-dimensional model of ovarian cancer. J Biomed Opt, 2013. 18(9): p. 098004.

49. Bartusik, D., D. Aebisher, A. Ghogare, G. Ghosh, I. Abramova, T. Hasan, and A. Greer, A fiberoptic (photodynamic therapy type) device with a photosensitizer and singlet oxygen delivery probe tip for ovarian cancer cell killing. Photochem Photobiol, 2013. 89(4): p. 936-41.

50. Goff, B.A., J. Blake, M.P. Bamberg, and T. Hasan, Treatment of ovarian cancer with photodynamic therapy and immunoconjugates in a murine ovarian cancer model. British Journal of Cancer, 1996. 74(8): p. 1194-1198. 
51. Samkoe, K.S., A. Chen, I. Rizvi, J.A. O'Hara, P.J. Hoopes, S.P. Pereira, T. Hasan, and B.W. Pogue, Imaging tumor variation in response to photodynamic therapy in pancreatic cancer xenograft models. Int J Radiat Oncol Biol Phys, 2010. 76(1): p. 251-9.

52. Bown, S.G., A.Z. Rogowska, D.E. Whitelaw, W.R. Lees, L.B. Lovat, P. Ripley, L. Jones, P. Wyld, A. Gillams, and A.W.R. Hatfield, Photodynamic therapy for cancer of the pancreas. Gut, 2002. 50(4): p. 549-557.

53. Huggett, M.T., M. Jermyn, A. Gillams, R. Illing, S. Mosse, M. Novelli, E. Kent, S.G. Bown, T. Hasan, B.W. Pogue, and S.P. Pereira, Phase I/II study of verteporfin photodynamic therapy in locally advanced pancreatic cancer. Br J Cancer, 2014. 110(7): p. 1698-704.

54. Selvendiran, K., A. Bratasz, M.L. Kuppusamy, M.F. Tazi, B.K. Rivera, and P. Kuppusamy, Hypoxia induces chemoresistance in ovarian cancer cells by activation of signal transducer and activator of transcription 3. Int J Cancer, 2009. 125(9): p. 2198-204.

55. Sibenaller, Z.A., J.L. Welsh, C. Du, J.R. Witmer, H.E. Schrock, J. Du, G.R. Buettner, P.C. Goswami, J.A. Cieslak, 3rd, and J.J. Cullen, Extracellular superoxide dismutase suppresses hypoxia-inducible factor-1alpha in pancreatic cancer. Free Radic Biol Med, 2014. 69: p. 357-66.

56. Wang, Y., J. Ma, H. Shen, C. Wang, Y. Sun, S.B. Howell, and X. Lin, Reactive oxygen species promote ovarian cancer progression via the HIF-1alpha/LOX/E-cadherin pathway. Oncol Rep, 2014. 32(5): p. 2150-8.

57. Wang, Y., L. Dong, H. Cui, D.H. Shen, Y. Wang, X.H. Chang, T.Y. Fu, X. Ye, and Y.Y. Yao, Upregulation of mitochondrial antioxidation signals in ovarian cancer cells with aggressive biologic behavior. J Zhejiang Univ Sci B, 2011. 12(5): p. 346-56.

58. Saunders, J.A., L.C. Rogers, C. Klomsiri, L.B. Poole, and L.W. Daniel, Reactive oxygen species mediate lysophosphatidic acid induced signaling in ovarian cancer cells. Free Radic Biol Med, 2010. 49(12): p. 2058-67.

59. Bao, L.J., M.C. Jaramillo, Z.B. Zhang, Y.X. Zheng, M. Yao, D.D. Zhang, and X.F. Yi, Nrf2 induces cisplatin resistance through activation of autophagy in ovarian carcinoma. Int J Clin Exp Pathol, 2014. 7(4): p. 1502-13.

60. Cho, J.M., S. Manandhar, H.R. Lee, H.M. Park, and M.K. Kwak, Role of the Nrf2-antioxidant system in cytotoxicity mediated by anticancer cisplatin: implication to cancer cell resistance. Cancer Lett, 2008. 260(1-2): p. 96-108.

61. Hong, Y.B., H.J. Kang, S.Y. Kwon, H.J. Kim, K.Y. Kwon, C.H. Cho, J.M. Lee, B.V. Kallakury, and I. Bae, Nuclear factor (erythroid-derived 2)-like 2 regulates drug resistance in pancreatic cancer cells. Pancreas, 2010. 39(4): p. 463-72.

62. Yi, Y.W. and S. Oh, Comparative analysis of NRF2-responsive gene expression in AcPC-1 pancreatic cancer cell line. Genes Genomics, 2015. 37: p. 97-109.

63. Walsh, N., A. Larkin, N. Swan, K. Conlon, P. Dowling, R. McDermott, and M. Clynes, RNAi knockdown of Hop (Hsp70/Hsp90 organising protein) decreases invasion via MMP-2 down regulation. Cancer Lett, 2011. 306(2): p. 180-9.

64. Kang, H.J., H.S. Moon, and H.W. Chung, The expression of FAS-associated factor 1 and heat shock protein 70 in ovarian cancer. Obstet Gynecol Sci, 2014. 57(4): p. 281-90.

65. Golab, J., D. Olszewska, P. Mroz, K. Kozar, R. Kaminski, A. Jalili, and M. Jakobisiak, Erythropoietin restores the antitumor effectiveness of photodynamic therapy in mice with chemotherapyinduced anemia. Clin Cancer Res, 2002. 8(5): p. 1265-70.

66. Josefsen, L.B. and R.W. Boyle, Photodynamic therapy and the development of metal-based photosensitisers. Met Based Drugs, 2008. 2008: p. 276109.

67. Kessel, D. and R.D. Poretz, Sites of photodamage induced by photodynamic therapy with a chlorin e6 triacetoxymethyl ester (CAME). Photochem Photobiol, 2000. 71(1): p. 94-6. 


\section{Artwork with Captions}

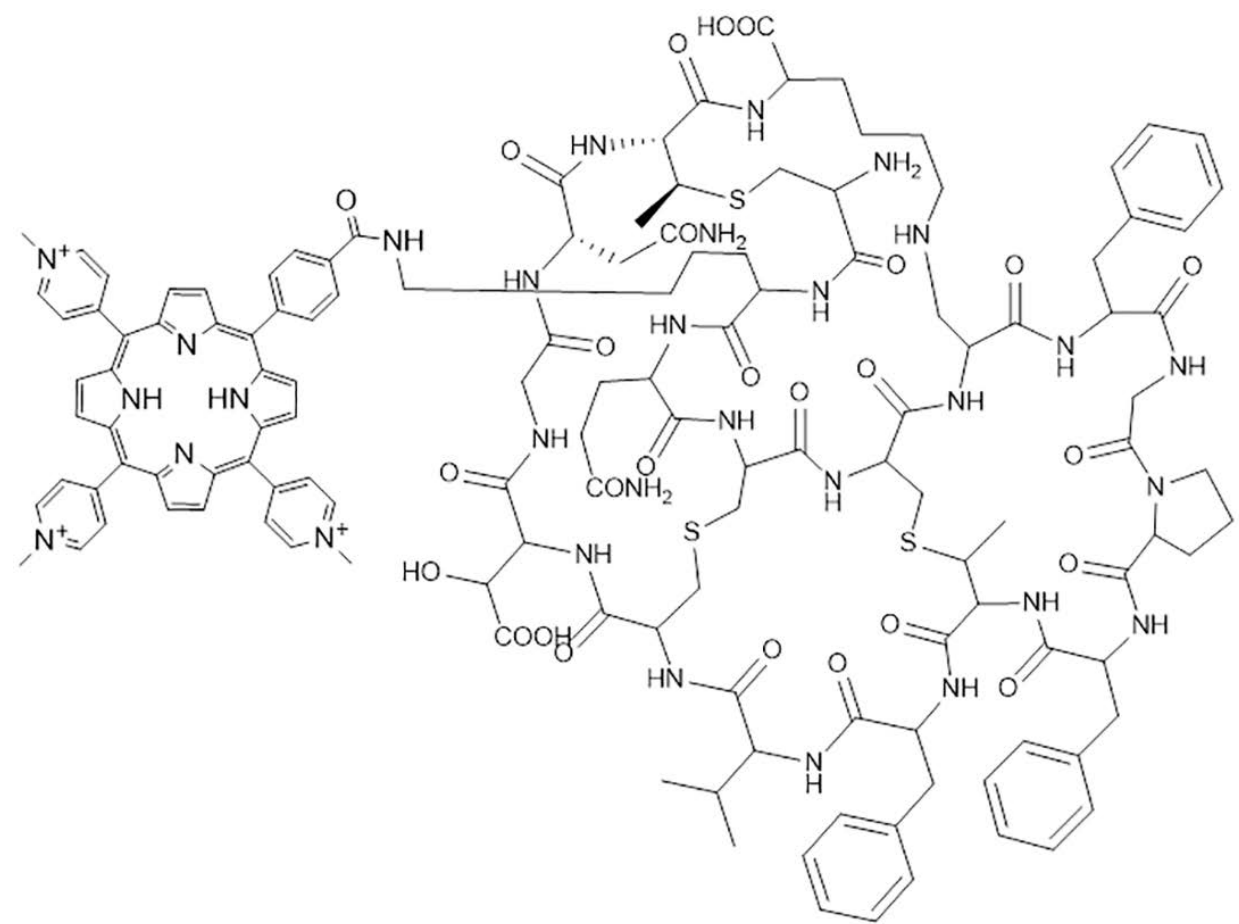

Figure 1: Structure of duramycin-porphyrin conjugate. A covalent amide bond was formed through the reaction with the NHS ester of the porphyrin 5-[4-( $N$-succinimidyloxycarbonyl)phenyl]-10,15,20-tris(4methylpyridinium) porphyrin trichloride and the $\varepsilon$-amino group of the lysine residue at duramycin's $N$ terminal in the organic solvent DMSO.

1.5 column fitting image 

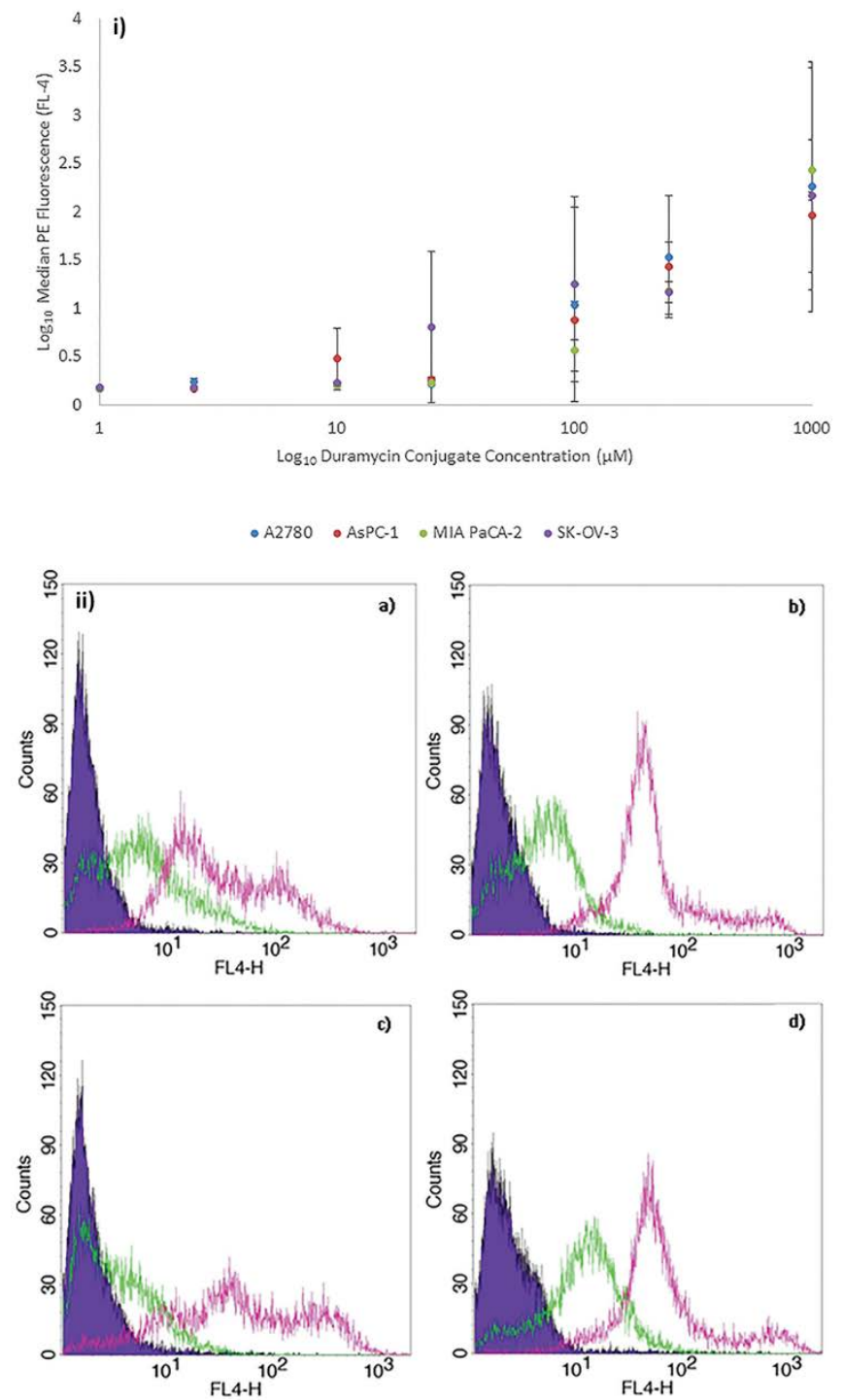

Figure 2: Detection of cell surface PE on ovarian and pancreatic cancer cell lines using duramycinporphyrin conjugate. i) $\log _{10}$ median PE fluorescence (FL-4 flow cytometer channel, $635 \mathrm{~nm}$ laser) was used to express detected levels of PE. The conjugate was able to detect PE on the cell surface of all 4 cancer cell lines, A2780, AsPC-1, MIA PaCa-2 and SK-OV-3, in a concentration dependent manner. Error bars show standard deviation of 2 replicates. ii) Flow cytometry histograms showing detectable shift in fluorescence on a) A2780, b) AsPC-1, c) MIA PaCa-2 and d) SK-OV-3 cells (purple) using $0.1 \mu \mathrm{M}$ (green) and $10 \mu \mathrm{M}$ (pink) duramycin-porphyrin conjugate.

1 column fitting image 


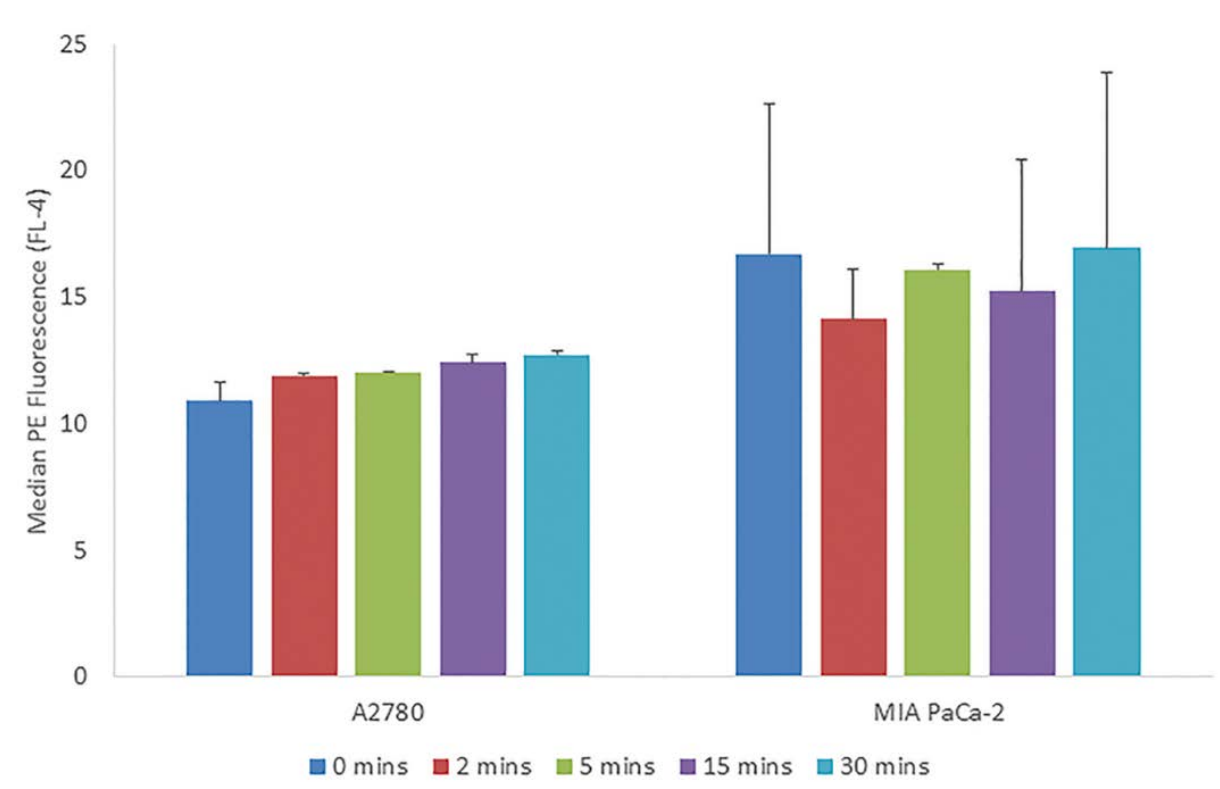

Figure 3: Competitive binding for PE between pre-bound duramycin-porphyrin conjugate and unconjugated duramycin. The unconjugated duramycin was unable to compete against the conjugate for cell surface PE on the cancer cell lines A2780 and MIA PaCa-2. The median PE fluorescence of MIA $\mathrm{PaCa}-2$ remained constant, within standard deviation, at each interval across the 30 minute time course. However the median PE fluorescence of A2780 increased slightly over time. Error bars show standard deviation of 2 replicates.

1.5 column fitting image 

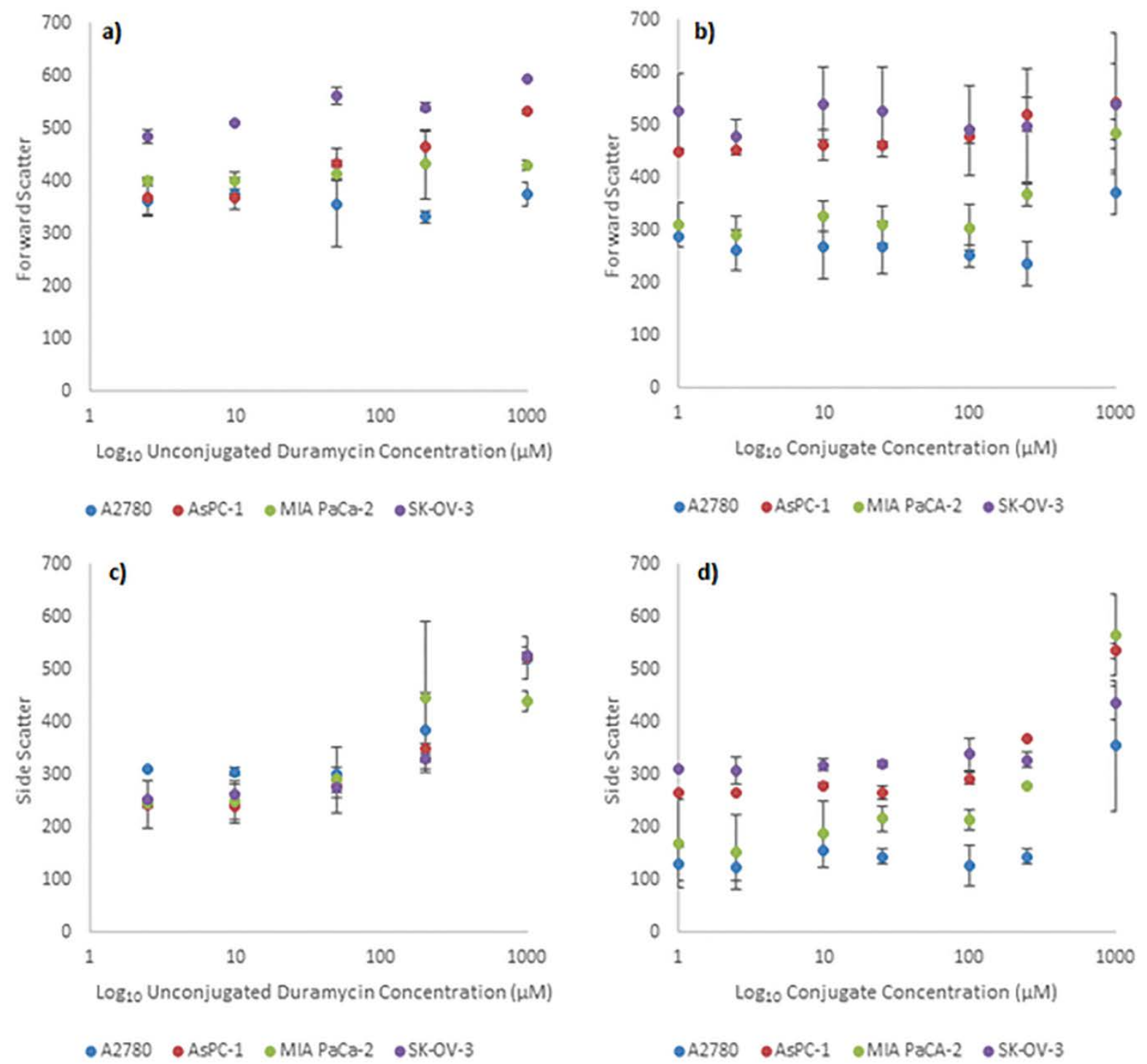

Figure 4: The effect of duramycin-porphyrin conjugate on the forward scatter and side scatter properties of ovarian and pancreatic cancer cell lines. The effect on FSC of a) unconjugated duramycin and b) duramycin-porphyrin conjugate and the effect on SSC of c) unconjugated duramycin and d) duramycin-porphyrin conjugate. Unconjugated duramycin has the ability to increase FSC (cell size) of AsPC- 1 cells at $>50 \mu \mathrm{M}$ and increase SSC (cell granularity) of A2780, AsPC-1, MIA PaCa-2 and SK-OV-3 at $>200 \mu \mathrm{M}$. Duramycin-porphyrin conjugate slightly increased FSC of A2780 and MIA PaCa-2 at $1 \mathrm{mM}$. SSC was increased in A2780 and SK-OV-3 when treated with $1 \mathrm{mM}$ conjugate and AsPC-1 and MIA PaCa-2 when treated with $>250 \mu \mathrm{M}$ conjugate. Error bars show standard deviation of 2 replicates.

2 column fitting image 

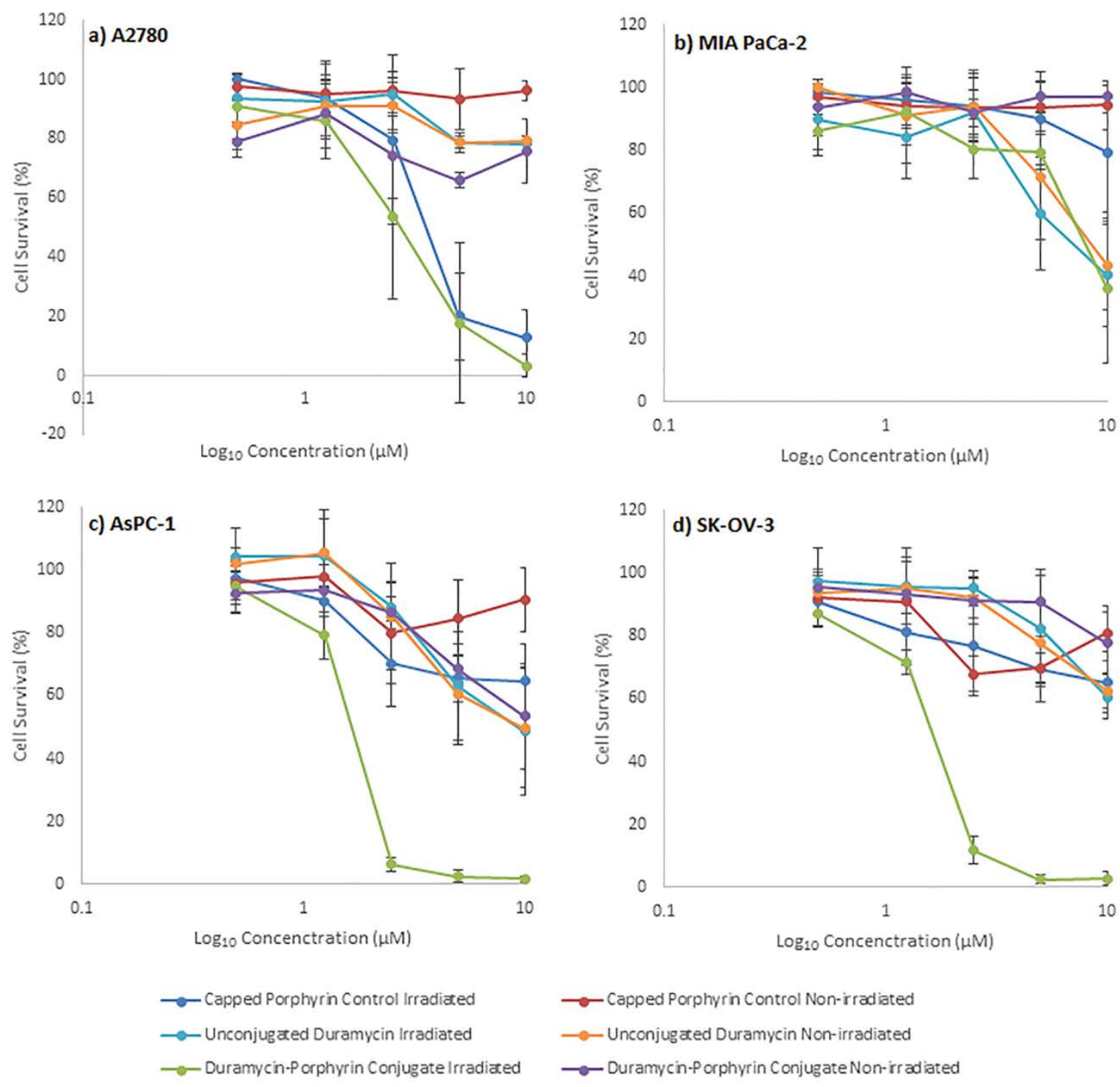

Figure 5: PDT Treatment of ovarian and pancreatic cancer cell lines. The irradiated duramycinporphyrin conjugate at concentrations $>2.5 \mu \mathrm{M}$ significantly reduced cell survival of AsPC-1, A2780 and SK-OV-3 cells when compared to the non-irradiated conjugate. The irradiated conjugate $>5 \mu \mathrm{M}$ significantly reduced cell survival of MIA PaCa-2 cells when compared to the non-irradiated conjugate. a) The unconjugated duramycin caused a slight reduction in cell survival of A2780 cells at concentrations $>5 \mu \mathrm{M}$. The irradiated capped porphyrin treated cells showed similar levels of cytotoxicity as the irradiated conjugate treated cells at concentrations $>5 \mu \mathrm{M}$. b) The irradiated capped porphyrin reduced cell survival of MIA PaCa-2 cells slightly at the highest concentration of $10 \mu \mathrm{M}$. Reduction in cell survival in conjugate treated cells was not significantly different to unconjugated duramycin treated cells. c) and d) Both AsPC-1 and SK-OV-3 showed dark toxicity at concentrations with non-irradiated conjugate $>5$ $\mu \mathrm{M}$. The irradiated capped porphyrin control slightly reduced cell survival at $10 \mu \mathrm{M}$. Unconjugated duramycin showed cytotoxic effect in a concentration dependent manner. Error bars show standard deviation of 3 independent experiments with 4 repetitions each.

2 column fitting image 


\section{Supplementary Data}

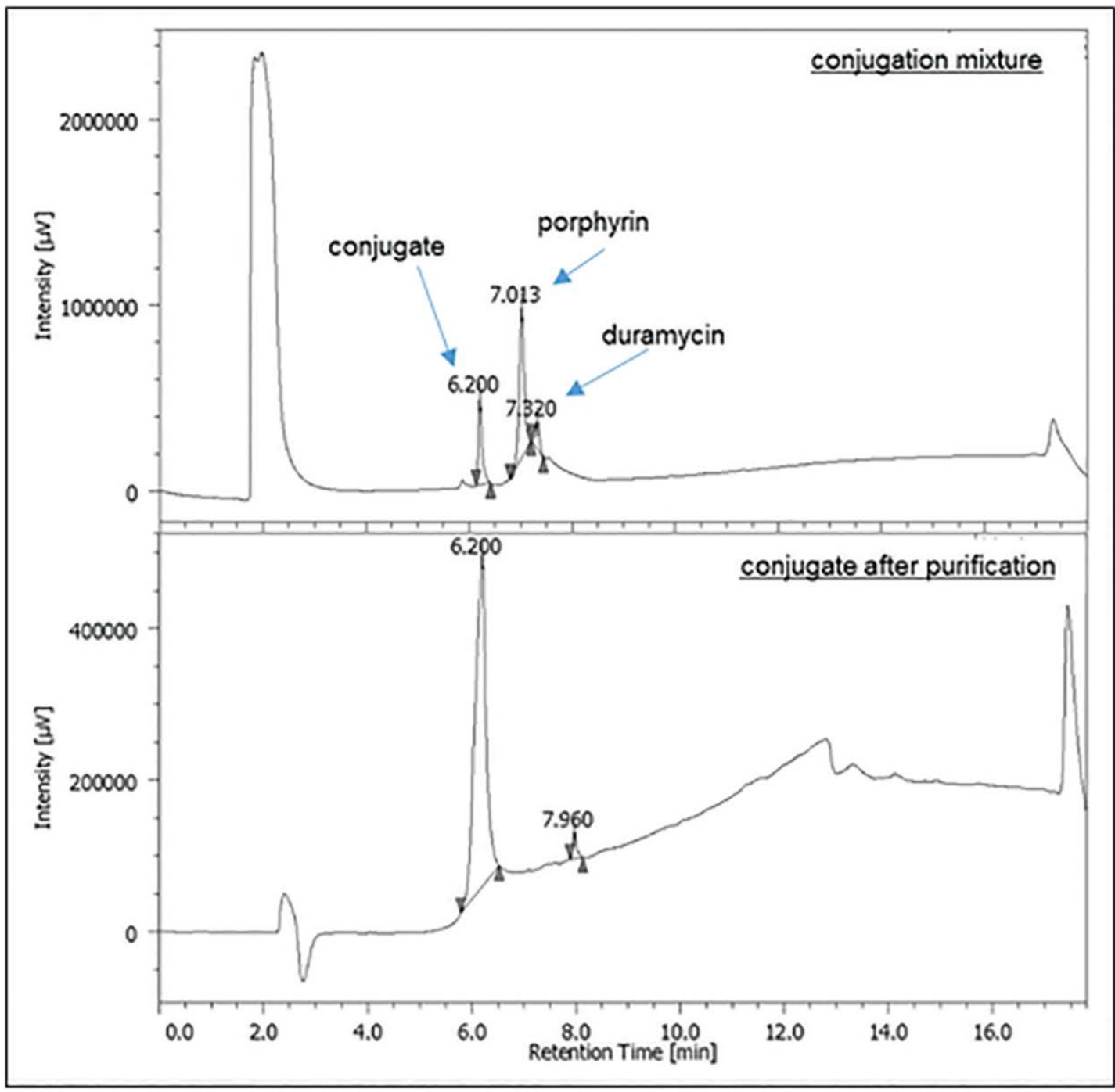

Supplementary Figure S-1: Semi-preparative HPLC of duramycin-porphyrin conjugate. Duramycinporphyrin conjugate was isolated by HPLC at $R_{t}=6.20$ minutes with the additional collection of unreacted porphyrin at $R_{t}=7.01$ and duramycin at $R_{t}=7.32$ minutes (upper trace). The conjugate was purified by HPLC and collected at $R_{t}=6.20$ minutes (lower trace). The break in the trace line on the lower trace represents the void time in which the solvent front eluted (as seen on upper trace). The small peak at $\mathrm{R}_{\mathrm{t}}=7.96$ is a discrepancy within the instrument rather than the detection of another compound. 


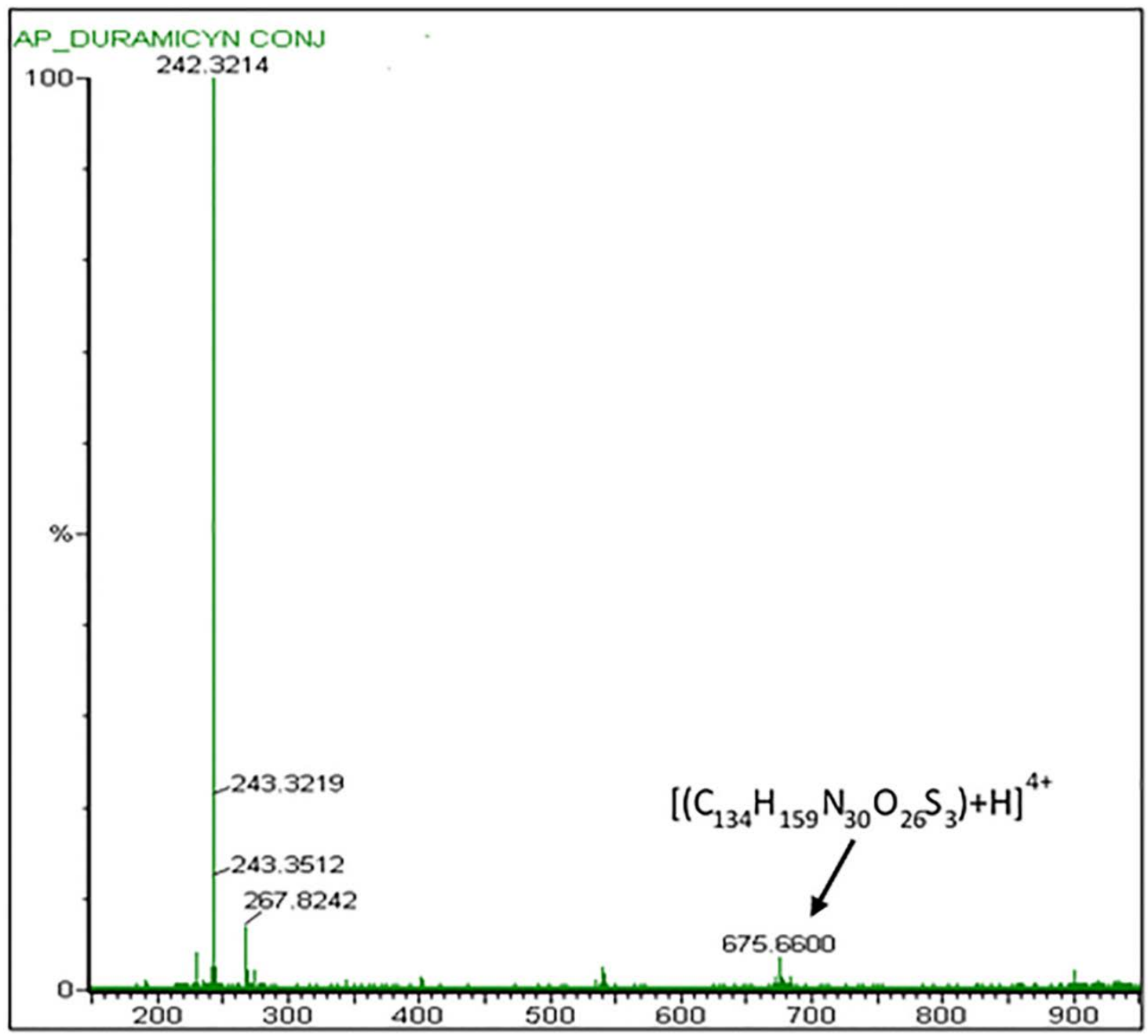

Supplementary Figure S-2: Electron ionising mass spectrometry of duramycin-porphyrin conjugate. The peak for the conjugate was found to be ESI-MS (+): $675.66\left[\left(\mathrm{M}+4 \mathrm{H}^{+}\right) / 4\right]^{4+}$ where the expected was 675.67. Conjugate retention time; $R_{t}=7.34$ minutes. The peaks at $<300.00$ were unidentified but were presumed to be a discrepancy within the machine most likely due to an impurity within the mass spectrometer. 